\title{
IPO Market Timing and Capital Structure: Evidences from Brazil
}

\author{
Luiz Felipe Jostmeier Vallandro ${ }^{1,3}$, João Zani ${ }^{2,3}$ \& Carlos Eduardo Schonerwald da Silva ${ }^{4,5}$ \\ ${ }^{1} \mathrm{PhD}$ Student in Business Administration at Universidade do Vale do Rio dos Sinos, UNISINOS, Brazil \\ ${ }^{2} \mathrm{PhD}$ in Business Administration at Federal University of Rio Grande do Sul, UFRGS, Brazil \\ ${ }^{3}$ Professor of Finance at Universidade do Vale do Rio dos Sinos, UNISINOS, Brazil \\ ${ }^{4} \mathrm{PhD}$ in Economics at University of Utah, USA \\ ${ }^{5}$ Professor of Economics at Federal University of Rio de Janeiro, UFRJ, Brazil
}

Correspondence: Luiz Felipe Jostmeier Vallandro, PhD Student in Business Administration at Universidade do Vale do Rio dos Sinos, UNISINOS, Brazil. E-mail: Ifelipe@ unisinos.br

Received: October 17, 2014

doi:10.5539/ibr.v8n1p24
Accepted: November 4, 2014

Online Published: December 25, 2014

\begin{abstract}
This article examines the occurrence of equity market timing through its effects on the capital structure of Brazilian companies that went public between 1997 and 2007. The results show the existence of equity market timing in the Brazilian stock market but its effects are not persistent in the long-run on the capital structure.
\end{abstract}

Keywords: capital structure, leverage, market timing, initial public offering, emerging markets

\section{Introduction}

The theoretical framework and the empirical tests associated to the theory of the static trade-off and pecking order (Myers, 1984; Myers \& Majluf, 1984) have revealed ambiguous and insufficient theoretical predictions and empirical results as to explain how companies determine their capital structure. At the same time, there are a number of empirical studies that have documented alternative explanations for part of the decisions about the capital structure of companies. One of these currents defends the occurrence of equity market timing by managers who are able to identify windows of opportunities when the equity is less costly due to mispricing. This proposition is not new, as a number of empirical studies have indirectly suggested its existence when they indicate that decisions to issue debt and equity are affected by past stock performance, interest rate costs and time-varying costs of adverse selection (Guney \& Iqbal-Hussain, 2010).

In this context, Baker and Wurgler (2002) formalized the equity market timing theory (EMTT), which can be defined as the practice of issuing shares when prices are high and buying them back when prices are low. The goal would be to make use of market timing as a way to make gains with possible temporary fluctuations in the cost of capital, compared to the cost of other sources of capital. This practice would allow managers to use specific market times to form the capital structure of their organizations - taking advantage of the lower cost of capital at the time - and choose equity as the source of financing. It may be assumed that the share issuance would occur when there was a high ratio between the market value and the book value of the firm (or low cost of capital) and, likewise, the buyback would happen when the price was low (or high cost of capital). The assumptions of the equity market timing theory also assume that firms tend to issue equity when investors are thrilled with the expectations of future earnings.

According to Baker and Wurgler (2002), the equity market timing theory can be understood from two perspectives. The first is to identify the existence of market timing in the formation of the capital structure of companies, i.e., if companies use, or not, the windows of market opportunities to issue shares. The second approach is whether the impacts of market timing are persistent in the long-run or only occur in the short-run, that is, if companies adopt this practice continuously in order to structure their capital, or whether this practice is temporary and companies raise their debt levels again. According to Baker and Wurgler (2002), at first sight, a short-term impact is expected.

In this sense, in case the companies manage to rebalance their leverage with a certain frequency, market timing will not have a persistent impact on capital structure (Flannery \& Rangan, 2006). On the other hand, if the rebalancing is not verified, the use of market timing can be considered as a practice in the financing decisions of 
the firm. The issuance of shares in this case would be the result of constant attempts to find the right market time for these new issuances.

Based on these assumptions, the focus of this work fell on both the empirical verification of the existence of market timing in the short-run, as well as on its long-term persistence in the formation of the capital structure of the Brazilian companies that held initial public offering (IPO) in the Securities, Commodities and Futures Exchange from Sao Paulo (BM\&F Bovespa) between 1997 and 2007.

In order to enable the research, the work adapted the main tests used by Baker and Wurgler (2002). As dependent variables, book leverage and market leverage were used. The independent variables used were the two measures of market-to-book (MB), the same used by Baker and Wurgler (2002) and later by Alti (2006) and Hovakimian (2006) to determine the company's value.

The main findings indicate that the companies that went public during this period used windows of opportunities to raise funds to finance their projects through the issuance of equity, taking advantage of the low cost of this source of capital. In this sense, there was evidence of the existence of equity market timing in the short-run. However, their long-run effects were not sustained, which opposes the results obtained by Baker and Wurgler (2002) for the US market, but maintains correspondence with the results reported for the UK market (Guney \& Iqbal-Hussain, 2010), the Netherlands (De Bie \& De Haan, 2007) and Brazil (Rossi Júnior \& Marotta, 2010; Rossi Júnior \& Céspedes, 2008).

The paper is organized as follows. Section 2 presents a summary of the main studies published about the theory of equity market timing. In section 3, we present the methodology developed for the empirical research. Section 4 discusses the main results, and Section 5 presents the conclusions.

\section{Empirical Evidence on Equity Market Timing}

It can be considered that the work of Baker and Wurgler (2002) was the starting point of the investigations about the theory of equity market timing on the capital structure of companies. These authors suggest that rational managers are able to take advantage of irrational investors by identifying windows of opportunities to issue and repurchase shares on favorable terms to the current shareholders due to the lower cost of equity as a result of market mispricing. Baker and Wurgler (2002) tested the theory for a set of 2,839 companies that went public in the United States between the years 1968 and 1999, noting that the fluctuations of the MB had long-term effects on corporate leverage. The evidence indicated that this is an important element in the financing decisions of the company. The results were consistent with the hypothesis that market timing has a large and persistent impact on capital structure.

The main finding of these authors was that companies with low leverage were those that raised funds when the MB ratio was high, while companies with high leverage were those that raised funds when their market value was low. The influence of past market values in the capital structure was significant and allowed them to state that companies take the windows of opportunities in the capital market to issue or buy back shares and that the effects of this strategy are persistent in the long-run.

Different empirical studies have found support for the hypothesis of market timing in the formation of the capital structure of companies. However, evidence has been ambiguous as to the existence of long-run impact of market timing on capital structure (Guney \& Iqbal-Hussain, 2010). Among the main empirical approaches are the works of Huang and Ritter (2005), Elliott, Koëter-Kant and Warr (2007), Alti (2006), Hovakimian (2006), De Bie and De Haan (2007) and Guney and Iqbal-Hussain (2010).

Huang and Ritter (2005) examined the patterns of external financing of American companies in the period 1964-2001, comparing the theories of static tradeoff and pecking order in relation to market timing. The results indicated that American businesses finance their deficit of funds at much higher proportions through the issuance of shares when the cost of capital is low, in relation to other sources. Decisions regarding the issuance of equity have a prolonged effect on the capital structure, even if controlled by other determinants and if the time adjustment toward the target leverage is slow. The results were consistent with the theory of market timing.

As an alternative way to analyze the impact of market timing on the financing decisions of companies, Elliott, Koëter-Kant and Warr (2007) criticized the use of MB and developed an evaluation model based on the residual income to decompose the MB. The authors argue that their method provides a better measurement because it avoids the many interpretation problems contained in $\mathrm{MB}$, such as growth opportunities, information asymmetry and mispricing. Based on this method, they found a strong positive relationship between the level of overvaluation of companies and the proportion of foreign financing of the deficit of funds that happened due to the issuance of equity, consistent with the theory of market timing. 
Alti (2006) conducted a study on the US market between 1971 and 1999 to investigate how market timing affects the capital structure based on a single financing event, the initial public offering. The author used almost the same database of Baker and Wurgler (2002), but separated the IPOs in periods of issuance when the market was hot (hot-market) and periods when the market was cold (cold-market). The results confirm that companies issue higher volumes of shares when the market is hot. On the other hand, it was found that after the IPO, companies that went public in the hot-market had higher debt ratios than those that did it in the cold-market, demonstrating that market timing does not persist in the long-run. The results of the research also show that the effect of market timing lasts only two years. After this period, companies rebalance debt levels to previous levels.

Notwithstanding, Hovakimian (2006) did not find persistence in the long-run to the effects of market timing on the capital structure of US companies. The author surveyed a sample of firms between 1983 and 2002, noting that the effects on equity issuance are minor and transient. This implies that opportune moments for stock transactions would not be responsible for the long-term impacts of the MB on leverage.

De Bie and De Haan (2007), using a sample of Dutch companies that went public between 1983 and 1997 and Guney and Iqbal-Hussain (2010), using a sample of UK companies between 1979 and 2008, found support for the existence of IPO market timing, but the market timing showed no persisting effects on the capital structure of the companies in both countries.

In emerging capital markets such as in Brazil, studies that relate equity market timing and capital structure are incipient.

Basso, Mendes and Kayo (2009) tested the theory of market timing based on the assumptions of Baker and Wurgler (2002) for a sample of 50 companies that went public in the Brazilian market between 1996 and 2002. The results did not support the existence of market timing in Brazil. The main finding was that the leverage of the companies decreases in the first year after the IPO, but, in sequence, increases again, which goes against the theory. Additionally, no statistical significance was found for the variables MB, asset tangibility, profitability and company size, to explain the leverage of the public companies in Brazil.

Rossi Junior and Céspedes (2008) conducted a study for the Brazilian capital market from a sample of all Brazilian companies listed in BM\&F Bovespa between 1996 and 2006. The work focused on the first approach of the theory, which is only to verify the existence of market timing, but not its relative persistence in the long run. Based on this purpose, the authors found evidence of the presence of market timing in the Brazilian stock market.

Recently, Rossi Junior and Marotta (2010) analyzed the behavior of the Brazilian companies that made IPO between 2004 and 2007. Following the criteria established by Alti (2006), the offerings were separated between hot-market and cold-market. The main findings suggest that companies adopt the strategy of market timing, issuing a higher volume of equity during the hot-market but the effects are not persistent and companies return to raise their debt levels in a period of less than two years after the IPO. The results have shown that the effects of the market timing strategy are limited to the short-run.

\section{Methodology}

\subsection{Hypotheses}

In order to conduct further studies to verify the occurrence of equity market timing in the Brazilian capital market, the following research hypotheses were established:

$\mathrm{H} 0$ : There is no occurrence of equity market timing in the determination of the capital structure of companies in Brazil.

H1: There is occurrence of equity market timing in the determination of the capital structure of companies in Brazil.

$\mathrm{H} 2$ : There is occurrence of equity market timing in the determination of the capital structure of the companies in Brazil in the short-run but it does not persist in the long-run.

H3: There is occurrence of equity market timing in the determination of the capital structure of companies in Brazil in the short-run and it persists in the long-run.

\subsection{Sample Composition}

The sample consisted of all IPOs conducted on the BM\&F Bovespa and registered in the Securities and Exchange Commission (CVM) between 1997 and 2007, excluding the sectors of finance, insurance and funds, 
due to their special characteristics of capital structure.

To the exclusion of companies in the sample, the same criteria of Baker and Wurgler (2002) were also adopted. In this context, companies in which the following conditions were identified, were not part of the final sample: (1) total assets less than R\$10 million; (2) belonging to the financial sectors, insurance and funds; (3) missing data on total assets in any year since the IPO until the moment the company went out of sample; (4) book leverage greater than 1 , since leverage was limited between 0 and $100 \%$, and (5) MB above 10 (only the company Lopes Brazil was excluded by this criterion, for presenting a MB of 44.8).

Accounting and market information were collected from the database of Economática. For the definition of the sample the same criteria defined by Baker and Wurgler (2002) were adopted: (1) public companies, listed in their respective capital markets, where it was possible to identify the date of the IPO and (2) established as the official criterion for the definition of the IPO date the first year in which data relative to the company's market values were reported in its database. The final sample consisted of 121 companies distributed according to Table 1:

Table 1. Number of companies in subsamples by IPO-year

\begin{tabular}{lcccccccc}
\hline & IPO & IPO+1 & IPO+2 & IPO+3 & IPO+4 & IPO+5 & IPO+6 & IPO+7 \\
\hline N. of Companies & 121 & 69 & 43 & 36 & 28 & 26 & 24 & 22 \\
\hline
\end{tabular}

From the definition of the sample, seven ranges were created for the subsamples, starting with IPO+1 and coming to a close in IPO+7. As the first range, the next full fiscal year after the year of the IPO was set up. As the second range, the second full fiscal year after the IPO, and then successively until IPO+7. As Baker and Wurgler (2002) explained, for the formation of each subsample (IPO+ $n$ ), only companies that survived $n$ years from the date of the IPO were included. The IPO range was used only in the summary statistics, since it was not possible to obtain data pre-IPO of a significant number of companies, which prevented the completion of the regressions that measured changes in leverage from year to year, starting from the pre-IPO period.

\subsection{Description of Variables}

Table 2 presents the dependent, independent and control variables used in this work. The measures of book leverage and market leverage were the dependent variables of the model. However, we proceeded a separation between gross debt (D) and gross financial debt (FD) for both measures of leverage, which resulted in four dependent variables. This procedure was adopted because, especially in emerging markets such as the Brazilian, many companies, even public companies, may access funding in the form of trade credit as a way of structuring their capital. For this reason, we observed leverage by the total gross debt, formed by the sum of current and non-current liabilities, and by the total gross financial debt, formed only by costly debt (Note 1).

Table 2. Description of variables

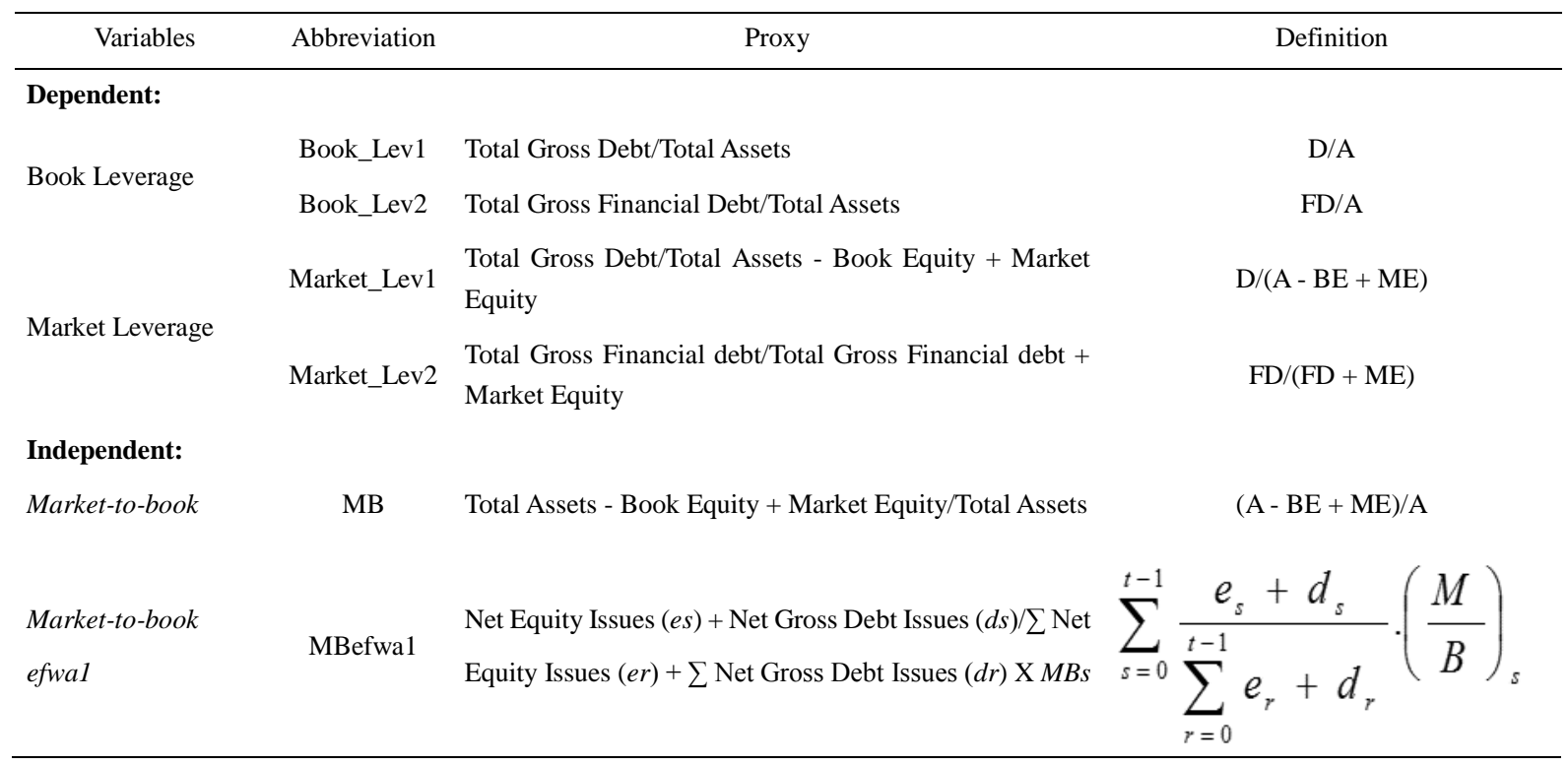




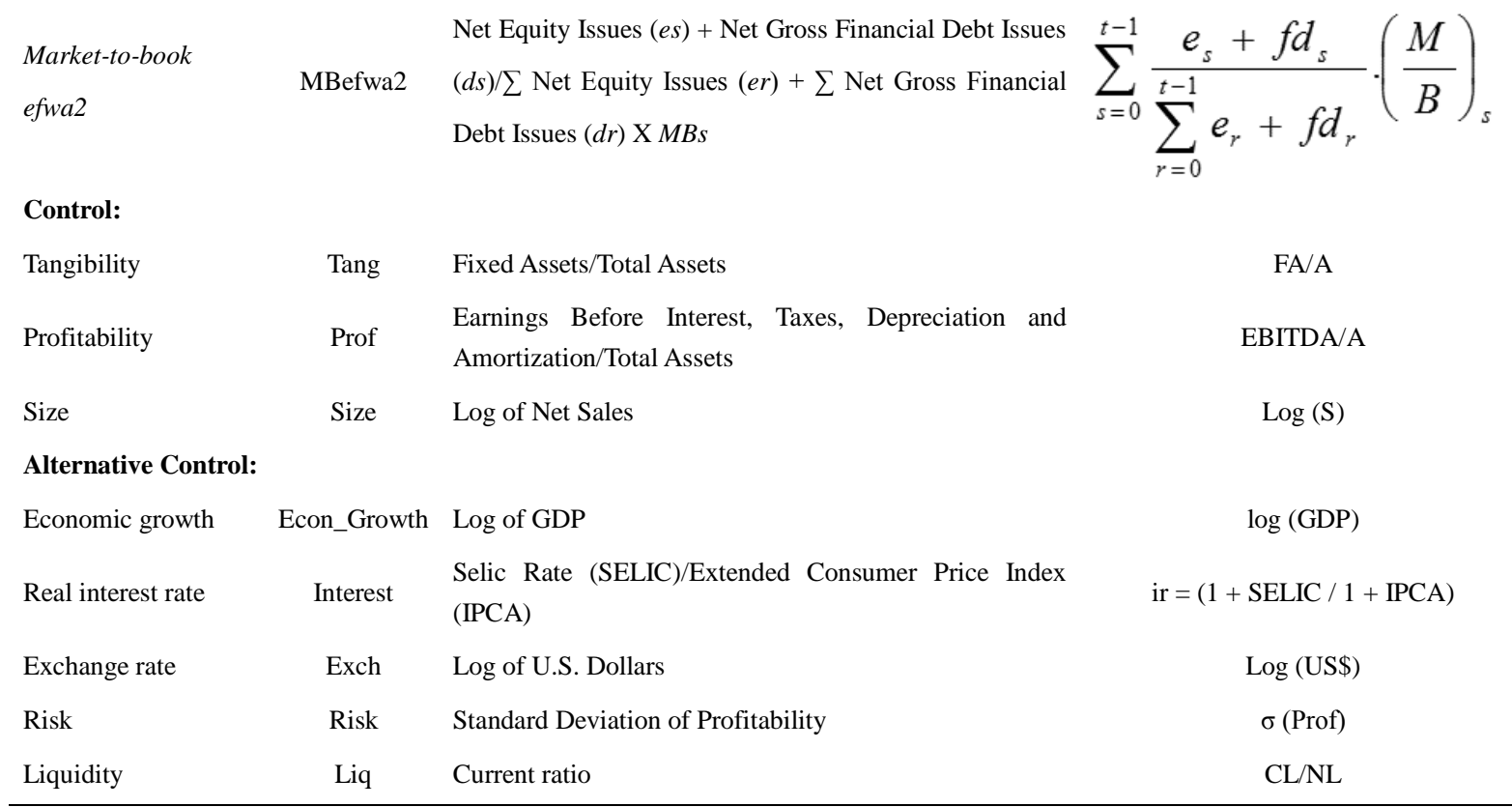

The control variables used as determinants of leverage were the same as proposed by Rajan and Zingales (1995) and also applied by Baker and Wurgler (2002) in their model. Additionally, five other alternative control variables were tested as possible determinants of leverage, reported in Table 2.

Unlike the theories of static tradeoff and pecking order, that assume a positive or negative relationship between leverage and its main determinants, the theory of equity market timing does not necessarily establish a direct or inverse relationship of leverage by firms with the major determinants of capital structure.

By the theory of market timing, a change in leverage levels based on the equity issue strategy is used by companies when they realize the windows of opportunities in the stock market and not effectively for their characteristics of size, liquidity, risk, tangibility or profitability. However, according to the independent variables shown in Table 2, an inverse relationship between leverage and the measures of market-to-book is expected, since firms with a greater MB ratio tend to issue more shares in order to take advantage of the overvaluation of prices of these shares and the low cost equity funds, requiring less leverage, as the market timing theory predicts.

\subsection{Empirical Strategy}

The methodology of Baker and Wurgler (2002) for the empirical verification of the existence of market timing in the Brazilian market was adopted. The model applied aimed to verify whether the market conditions, measured by market-to-book, determine the annual change in the capital structure of companies. Four operational definitions of capital structure, two by accounting and two by market, were adopted, as described in Table 2 . Other determinants of financial leverage documented in the literature were added as control variables. The basic model has the following specification:

$$
\Delta L E V_{i t}=\beta_{0}+\beta_{1} M B_{i, t-1}+\beta_{2} T A N G_{i, t-1}+\beta_{3} P R O F_{i, t-1}+\beta_{4} S I Z E_{i, t-1}+\beta_{5} L E V_{i, t-1}+u_{i t}
$$

Where the capital structure $(\triangle \mathrm{LEV})$ is the dependent variable, market-to-book $(\mathrm{MB})$ the independent variable and tangibility (TANG), profitability (PROF), size (SIZE) and capital structure (LEV) (Note 2) the control variables. All explanatory variables were lagged in one period.

An extended model was used to capture the long-term effect of market timing on capital structure. The extension involved the inclusion of the variable "external finance weighted-average" market-to-book ratio (MBefwa) as an explanatory variable. The extended model had the following specification:

$$
\Delta L E V_{i t}=\beta_{0}+\beta_{1} M B_{e f w a_{i, t-1}}+\beta_{2} M B_{i, t-1}+\beta_{3} T A N G_{i, t-1}+\beta_{4} P R O F_{i, t-1}+\beta_{5} S I Z E_{i, t-1}+\beta_{6} L E V_{i, t-1}+u_{i t}
$$

Baker and Wurgler (2002) formulated an alternative measure for the MB variable, they called it the external finance weighted average of the ratio between the market value and the book value (external finance weighted 
average, market-to-book ratio - MBefwa). The model of Baker and Wurgler indicates that the MB ratio would affect the levels of leverage of companies at least in the short-run, due to net share issuance. However, the occurrence of equity market timing could be just a local opportunity, whose effect is quickly rebalanced. On the other hand, if managers do not rebalance leverage levels, market timing can have a persistent effect, and historical values will help to understand why the leverage levels differ from one company to another. Therefore, the main variable used by these authors was the external finance weighted average, market-to-book ratio (MBefwa).

Understanding independent variable MBefwa is extremely relevant to the achievement of the empirical tests that attempt to identify the effects of market timing in the long-run. For a company observed in the period t-1, MBefwa represents the weighted average of a number of past market-to-book ratio, starting with the first available observation in the sample (the IPO year) and ending in t-1. The weight for each year is formed by dividing the sum of external financing through issuance of shares and the debt in the respective year and the sum of external financing through equity issuances and the debt from the first year (1) until the year t-1. For the computation of this variable, the minimum weight is set to zero. If any company has presented negative values in any year, these take zero value. This allows the formation of a weighted average. In each event, a weight of zero means that the variable did not contain information on market values in that year.

The issuance of shares is expressed by $e$ and debt issuance by $d$. The issuance of shares is given by the variation of equity minus the variation in retained earnings. The issuance of debt is given by the variation in debt. The criteria for establishing the debt are described in the first paragraph of subsection 3.3. Once the separation procedure between total gross debt and total financial gross debt was adopted, it was necessary to subdivide the independent variable MBefwa in two, resulting in MBefwa1 for the proxy that calculated the total gross issuance of debt and MBefwa2 for the proxy which calculated the issuance of the total gross financial debt.

To the regressions used in this work, econometric tests that enabled the correct estimation of the panels were applied.

To identify the model of estimating the panels, if by fixed effects (FE) or by random effects (RE), the Hausmann specification test was applied. For those regressions that indicated the use of RE as the best estimation model, the Breusch and Pagan (1980) test was additionally applied, which validated the use of the random effect for such regressions.

To identify the existence of autocorrelation, the tests from Bhargava, Franzini and Narendranathan (1982) and Baltagi and $\mathrm{Wu}$ (1999) were applied. For the detection of heteroskedasticity, the tests from White (1980) and Baltagi, Bresson and Pirotte (2006) were applied. The correction of the regressions, where there was the identification of autocorrelation and heteroskedasticity, was performed by applying the methods of Arellano (1987), Froot (1989) and Rogers (1993).

\section{Results}

Table 3 presents the summary statistics of the capital structure of the firms that composed the sample. The averages and standard deviations for the four measures of leverage, for the explanatory variable MB and for the control variables tangibility, profitability and size are presented in it. The purpose of obtaining the averages and the standard deviations is to identify a first signaling of the existence of market timing in the formation of the capital structure of these companies.

Table 3. Summary statistics

\begin{tabular}{|c|c|c|c|c|c|c|c|c|c|}
\hline \multirow{3}{*}{ Year } & & Book Lev1 & Book Lev2 & Market Lev1 & Market Lev2 & MB & Tang & Prof & Size \\
\hline & & Mean & Mean & Mean & Mean & Mean & Mean & Mean & Mean \\
\hline & $\mathrm{N}$ & (S.D.) & (S.D.) & (S.D.) & (S.D.) & (S.D.) & (S.D.) & (S.D.) & (S.D.) \\
\hline \multirow{2}{*}{ IPO } & 121 & 0.49 & 0.24 & 0.39 & 0.25 & 1.63 & 0.53 & 0.13 & 13.74 \\
\hline & & $(0.20)$ & $(0.20)$ & $(0.22)$ & $(0.20)$ & (1.11) & $(0.26)$ & $(0.10)$ & (1.97) \\
\hline \multirow{2}{*}{$\mathrm{IPO}+1$} & 69 & 0.50 & 0.26 & 0.41 & 0.27 & 1.55 & 0.56 & 0.14 & 13.85 \\
\hline & & $(0.20)$ & $(0.17)$ & $(0.22)$ & $(0.21)$ & (1.09) & $(0.24)$ & $(0.10)$ & (2.02) \\
\hline \multirow{2}{*}{$\mathrm{IPO}+2$} & 43 & 0.52 & 0.27 & 0.44 & 0.29 & 1.41 & 0.60 & 0.15 & 14.05 \\
\hline & & $(0.20)$ & $(0.17)$ & $(0.21)$ & $(0.21)$ & (1.03) & $(0.22)$ & $(0.10)$ & (1.99) \\
\hline
\end{tabular}




\begin{tabular}{|c|c|c|c|c|c|c|c|c|c|}
\hline \multirow{2}{*}{$\mathrm{IPO}+3$} & 36 & 0.52 & 0.27 & 0.45 & 0.30 & 1.37 & 0.60 & 0.15 & 14.06 \\
\hline & & $(0.20)$ & $(0.17)$ & $(0.21)$ & $(0.21)$ & (1.03) & $(0.21)$ & $(0.10)$ & (2.02) \\
\hline \multirow{2}{*}{$\mathrm{IPO}+4$} & 28 & 0.50 & 0.27 & 0.46 & 0.32 & 1.17 & 0.64 & 0.15 & 14.02 \\
\hline & & $(0.20)$ & $(0.17)$ & $(0.20)$ & $(0.21)$ & $(0.60)$ & (0.19) & $(0.09)$ & (2.11) \\
\hline \multirow{2}{*}{$\mathrm{IPO}+5$} & 26 & 0.49 & 0.27 & 0.46 & 0.31 & 1.17 & 0.63 & 0.15 & 14.04 \\
\hline & & $(0.20)$ & $(0.17)$ & $(0.19)$ & $(0.21)$ & $(0.61)$ & (0.19) & $(0.10)$ & (2.15) \\
\hline \multirow{2}{*}{$\mathrm{IPO}+6$} & 24 & 0.49 & 0.26 & 0.46 & 0.30 & 1.14 & 0.63 & 0.14 & 14.02 \\
\hline & & $(0.20)$ & $(0.17)$ & $(0.19)$ & $(0.21)$ & $(0.56)$ & $(0.20)$ & $(0.09)$ & (2.20) \\
\hline \multirow{2}{*}{$\mathrm{IPO}+7$} & 22 & 0.47 & 0.24 & 0.45 & 0.29 & 1.13 & 0.64 & 0.14 & 13.96 \\
\hline & & $(0.20)$ & $(0.16)$ & $(0.20)$ & $(0.21)$ & $(0.58)$ & (0.19) & $(0.10)$ & (2.25) \\
\hline
\end{tabular}

The book leverage measures indicate that in the year of the IPO, the average of the leverage of the Brazilian companies that went public between 1997 and 2007 was 49\%, by the criterion of total debt. After the IPO year, the level of debt rises to $50.4 \%$. In IPO+2, the leverage continues to grow and reaches $52 \%$; from then on it fell again, but not sharply, reaching the level of $47.2 \%$ in IPO+7. The behavior of the leverage measured by the total financial debt was similar. In the year of the IPO it was lower $(24.4 \%)$, but it grows up to IPO+2 (27.1\%), dropping again from then on, also mildly, reaching $24.3 \%$ in IPO+7.

Regarding market leverage the behavior is similar, where the leverage measured by the total debt averaged $38.8 \%$ in the year of the IPO, rising to $41.1 \%$ in IPO+1 and reaching its highest level in IPO+4 (46.5\%), becoming stable at that level until IPO+7. The same explanations can be used to describe the behavior of the market leverage as measured by the total financial debt.

For the variable MB, the highest value occurs in the subsample IPO, which averaged 1.62. As seen in the same table, where there were lower values for debt ratios during the same period, it can be seen that there is evidence for market timing in the short-run. However, the measurements of MB gradually fall after the first year, keeping closer the relationship between the market value and the book value, opposite to the theory's predictions, indicating that the market begins to correct the prices of these shares after the period of the IPO.

According to what was observed by the leverage means, it may be inferred that the theory of equity market timing occurs in the short-run, because of the reduction in the levels of leverage of the companies after the initial public offering, but this is not already supported in the first year after the IPO, since the leverage starts raising from this period on.

Tables 4 to 7 show panels with the different regressions applied to each of the dependent variables.

The panels shown in table 4 investigated the determinants of the annual changes in leverage. Two equations that had as dependent variable the measures of book leverage were regressed.

The panel A1 of table 4 reports the tests of the variation in book leverage by total debt. Only the variable tangibility was statistically significant at $10 \%$ for the subsamples IPO+5, IPO+6 and IPO+7. The signal found for the coefficient was positive, in line with the expectations, and the largest $\mathrm{R}^{2}$ calculated was $7.7 \%$ in IPO + 4 and IPO+5.

For panel A2, that examined the variation in book leverage by total financial debt, it appears that the explanatory variable MB was not statistically significant in any of the subsamples. However, the sign of the coefficient was positive, indicating a contrary relation to what the market timing theory suggests. The variable tangibility was positive and significant at $5 \%$ for all years, as expected. Through these results, the high coefficient for the MB was directly related to greater variations in the levels of leverage, i.e., overvalued companies would use debt the most, contrary to what the equity market timing theory suggests. 
Table 4. Determinants of annual changes in book leverage

\begin{tabular}{|c|c|c|c|c|c|c|c|c|c|}
\hline & N. Obs & Constant & MB t-1 & Tang t-1 & Prof $\mathrm{t}-1$ & Size t-1 & Book_Lev t-1 & $\mathrm{R}^{2}$ & Hausmann's Tes \\
\hline \multicolumn{10}{|c|}{ Panel A1: Changes in Book_Lev1 } \\
\hline \multirow[t]{2}{*}{$\mathrm{IPO}+1$} & 282 & -0.03 & -0.01 & 0.10 & 0.15 & 0.01 & -0.40 & 0.03 & FE \\
\hline & & & $(-0.62)$ & $(1.58)$ & $(1.62)$ & $(0.75)$ & $(-6.57)^{* * *}$ & & \\
\hline \multirow[t]{2}{*}{$\mathrm{IPO}+2$} & 256 & -0.04 & -0.01 & 0.10 & 0.15 & 0.01 & -0.40 & 0.06 & $\mathrm{FE}$ \\
\hline & & & $(-0.61)$ & $(1.57)$ & (1.61) & $(0.74)$ & $(-6.53)^{* * *}$ & & \\
\hline \multirow{2}{*}{$\mathrm{IPO}+3$} & 242 & -0.07 & 0.00 & 0.10 & 0.10 & 0.01 & -0.39 & 0.07 & $\mathrm{FE}$ \\
\hline & & & $(-0.28)$ & $(1.60)$ & $(1.01)$ & $(0.85)$ & $(-6.50)^{* * *}$ & & \\
\hline \multirow{2}{*}{$\mathrm{IPO}+4$} & 218 & 0.03 & 0.00 & 0.10 & 0.13 & 0.01 & -0.37 & 0.08 & $\mathrm{FE}$ \\
\hline & & & $(0.19)$ & $(1.63)$ & $(1.32)$ & $(0.38)$ & $(-6.55)^{* * *}$ & & \\
\hline \multirow{2}{*}{$\mathrm{IPO}+5$} & 210 & 0.03 & 0.00 & 0.10 & 0.14 & 0.01 & -0.36 & 0.08 & $\mathrm{FE}$ \\
\hline & & & $(0.17)$ & $(1.69)^{*}$ & $(1.40)$ & $(0.34)$ & $(-6.45)^{* * *}$ & & \\
\hline \multirow[t]{2}{*}{$\mathrm{IPO}+6$} & 200 & 0.00 & 0.00 & 0.10 & 0.13 & 0.01 & -0.35 & 0.07 & $\mathrm{FE}$ \\
\hline & & & $(-0.07)$ & $(1.67)^{*}$ & $(1.29)$ & $(0.47)$ & $(-6.23)^{* * *}$ & & \\
\hline \multirow[t]{2}{*}{$\mathrm{IPO}+7$} & 188 & -0.03 & 0.00 & 0.10 & 0.11 & 0.01 & -0.35 & 0.07 & $\mathrm{FE}$ \\
\hline & & & $(0.12)$ & $(1.65)^{*}$ & $(1.06)$ & $(0.56)$ & $(-6.30)^{* * *}$ & & \\
\hline \multicolumn{10}{|c|}{ Panel A2: Changes in Book_Lev2 } \\
\hline \multirow[t]{2}{*}{$\mathrm{IPO}+1$} & 282 & -0.26 & 0.0211 & 0.23 & 0.01 & 0.02 & -0.41 & 0.08 & $\mathrm{FE}$ \\
\hline & & & $(1.50)$ & $(2.45)^{* *}$ & $(0.11)$ & $(0.94)$ & $(-7.37)^{* * *}$ & & \\
\hline \multirow[t]{2}{*}{$\mathrm{IPO}+2$} & 256 & -0.26 & 0.0211 & 0.23 & 0.01 & 0.02 & -0.41 & 0.11 & $\mathrm{FE}$ \\
\hline & & & $(1.49)$ & $(2.44)^{* *}$ & $(0.11)$ & $(0.93)$ & $(-7.33)^{* * * *}$ & & \\
\hline \multirow[t]{2}{*}{$\mathrm{IPO}+3$} & 242 & -0.27 & 0.0179 & 0.23 & 0.02 & 0.02 & -0.39 & 0.11 & $\mathrm{FE}$ \\
\hline & & & $(1.26)$ & $(2.46)^{* *}$ & $(0.22)$ & $(0.95)$ & $(-7.37)^{* * * *}$ & & \\
\hline \multirow[t]{2}{*}{$\mathrm{IPO}+4$} & 218 & -0.20 & 0.0168 & 0.22 & 0.03 & 0.01 & -0.39 & 0.11 & FE \\
\hline & & & $(0.95)$ & $(2.35)^{* * *}$ & $(0.30)$ & $(0.72)$ & $(-7.15)^{* * *}$ & & \\
\hline \multirow[t]{2}{*}{$\mathrm{IPO}+5$} & 210 & -0.20 & 0.0174 & 0.22 & 0.03 & 0.01 & -0.39 & 0.11 & FE \\
\hline & & & $(0.97)$ & $(2.27)^{* *}$ & $(0.24)$ & $(0.71)$ & $(-7.01)^{* * *}$ & & \\
\hline \multirow[t]{2}{*}{$\mathrm{IPO}+6$} & 200 & -0.22 & 0.0107 & 0.22 & 0.03 & 0.01 & -0.38 & 0.10 & FE \\
\hline & & & $(0.55)$ & $(2.26)^{* *}$ & $(0.24)$ & $(0.80)$ & $(-6.70)^{* * *}$ & & \\
\hline \multirow[t]{2}{*}{$\mathrm{IPO}+7$} & 188 & -0.26 & 0.0177 & 0.21 & -0.04 & 0.01 & -0.36 & 0.10 & FE \\
\hline & & & $(0.98)$ & $(2.26)^{* *}$ & $(-0.50)$ & $(0.95)$ & $(-1.28)$ & & \\
\hline
\end{tabular}

***, **, * significant at $0.01,0.05,0.10$ respectively. Robust $\mathrm{t}(\mathrm{z})$ statistics are in parentheses.

The panels were estimated using Feasible Generalized Least Squares - FGLS regressions.

Regression panel A1: $\Delta$ Book_Lev1 ${ }_{i t}=\beta_{0}+\beta_{1} M B_{i, t-1}+\beta_{2}$ Tang $_{i, t-1}+\beta_{3} \operatorname{Prof}_{i, t-1}+\beta_{4}$ Size $_{i, t-1}+\beta_{5}$ Book_Lev1 $_{i, t-1}+u_{i t}$

Regression panel A2: $\Delta$ Book_Lev2 ${ }_{i t}=\beta_{0}+\beta_{1} M B_{i, t-1}+\beta_{2}$ Tang $_{i, t-1}+\beta_{3} \operatorname{Pr} f_{i, t-1}+\beta_{4}$ Size $_{i, t-1}+\beta_{5}$ Book_Lev $_{i, t-1}+u_{i t}$

Based on the results of table 4, we see a direct relationship between leverage and MB for the variation in book leverage calculated by the total financial debt, so these results are contrary to the expectations that was of finding an inverse relationship. One can verify, based on the analysis of the results presented in panels A, that the theory of equity market timing does not have empirical support in the Brazilian capital market.

Tables 5 and 6 present the determinants of leverage. This procedure consisted of regressing the four leverage measures, two by book leverage (panel B1 - table 5 and panel B3 - Table 6) and two by market leverage (Panel 
B2 - Table 5 and panel B4 - Table 6).

Table 5. Determinants of leverage (total gross debt)

\begin{tabular}{|c|c|c|c|c|c|c|c|c|c|}
\hline & N. Obs & Constant & MBefwa1 t-1 & MB t-1 & Tang $\mathrm{t}-1$ & Prof $t-1$ & Size $t-1$ & $\mathrm{R}^{2}$ & Hausmann's Test \\
\hline \multicolumn{10}{|c|}{ Panel B1: Book_Lev1 } \\
\hline \multirow{2}{*}{$\mathrm{IPO}+1$} & 238 & -0.01 & 0.01 & -0.03 & 0.04 & 0.28 & 0.04 & 0,08 & $\mathrm{RE}$ \\
\hline & & & $(-0.47)$ & $(-1.28)$ & $(-0.05)$ & $(-1.57)$ & $(1.65)^{*}$ & & \\
\hline \multirow{2}{*}{$\mathrm{IPO}+2$} & 219 & 0.23 & 0.01 & -0.02 & -0.01 & 0.15 & 0.02 & 0,07 & $\mathrm{RE}$ \\
\hline & & & $(0.73)$ & $(-0.91)$ & $(-0.10)$ & $(1.23)$ & $(1.14)$ & & \\
\hline \multirow{2}{*}{$\mathrm{IPO}+3$} & 206 & 0.31 & 0.01 & -0.02 & -0.03 & 0.13 & 0.02 & 0,07 & $\mathrm{RE}$ \\
\hline & & & $(0.74)$ & $(-0.80)$ & $(-0.27)$ & $(0.94)$ & $(0.84)$ & & \\
\hline \multirow{2}{*}{$\mathrm{IPO}+4$} & 182 & 0.37 & 0.02 & -0.01 & -0.04 & 0.20 & 0.01 & 0,16 & $\mathrm{RE}$ \\
\hline & & & $(0.95)$ & $(-0.22)$ & $(-0.30)$ & $(1.27)$ & $(0.55)$ & & \\
\hline \multirow[t]{2}{*}{$\mathrm{IPO}+5$} & 174 & 0.33 & 0.02 & -0.01 & -0.04 & 0.21 & 0.01 & 0,18 & $\mathrm{RE}$ \\
\hline & & & $(0.97)$ & $(-0.18)$ & $(-0.33)$ & $(1.35)$ & $(0.65)$ & & \\
\hline \multirow[t]{2}{*}{$\mathrm{IPO}+6$} & 164 & 0.35 & 0.01 & 0.00 & -0.05 & 0.20 & 0.01 & 0,20 & $\mathrm{RE}$ \\
\hline & & & $(0.68)$ & $(0.03)$ & $(-0.39)$ & $(1.21)$ & $(0.56)$ & & \\
\hline \multirow{2}{*}{$\mathrm{IPO}+7$} & 152 & 0.33 & 0.01 & 0.00 & -0.04 & 0.18 & 0.01 & 0,20 & $\mathrm{RE}$ \\
\hline & & & $(0.68)$ & $(0.11)$ & $(-0.36)$ & $(1.05)$ & $(0.54)$ & & \\
\hline \multicolumn{10}{|c|}{ Panel B2: Market_Lev1 } \\
\hline \multirow[t]{2}{*}{$\mathrm{IPO}+1$} & 238 & 0.33 & 0.01 & -0.11 & 0.07 & -0.06 & 0.01 & 0,32 & $\mathrm{RE}$ \\
\hline & & & $(0.44)$ & $(-4.18)^{* * *}$ & (1.11) & $(-0.39)$ & $(0.91)$ & & \\
\hline \multirow[t]{2}{*}{$\mathrm{IPO}+2$} & 219 & 0.52 & 0.02 & -0.10 & 0.06 & -0.20 & 0.00 & 0,30 & $\mathrm{RE}$ \\
\hline & & & $(0.63)$ & $(-4.01)^{* * *}$ & $(0.74)$ & $(-1.05)$ & $(0.24)$ & & \\
\hline \multirow[t]{2}{*}{$\mathrm{IPO}+3$} & 206 & 0.70 & 0.02 & -0.10 & 0.07 & -0.09 & -0.01 & 0,29 & $\mathrm{RE}$ \\
\hline & & & $(0.62)$ & $(-3.99)^{* * *}$ & $(0.85)$ & $(-0.40)$ & $(-0.46)$ & & \\
\hline \multirow[t]{2}{*}{$\mathrm{IPO}+4$} & 182 & 0.64 & 0.01 & -0.15 & 0.07 & 0.08 & 0.00 & 0,23 & $\mathrm{RE}$ \\
\hline & & & $(0.38)$ & $(-4.86)^{* * *}$ & $(0.77)$ & $(0.38)$ & $(-0.15)$ & & \\
\hline \multirow[t]{2}{*}{$\mathrm{IPO}+5$} & 174 & 0.63 & 0.01 & -0.15 & 0.09 & 0.09 & 0.00 & 0,23 & $\mathrm{RE}$ \\
\hline & & & $(0.36)$ & $(-4.81)^{* * *}$ & $(0.90)$ & $(0.44)$ & $(0.18)$ & & \\
\hline \multirow[t]{2}{*}{$\mathrm{IPO}+6$} & 164 & 0.62 & 0.02 & -0.17 & 0.09 & 0.13 & 0.00 & 0,21 & $\mathrm{RE}$ \\
\hline & & & $(0.63)$ & $(-4.90) * * *$ & $(0.87)$ & $(0.63)$ & $(-0.13)$ & & \\
\hline \multirow[t]{2}{*}{$\mathrm{IPO}+7$} & 152 & 0.59 & 0.02 & -0.16 & 0.09 & 0.04 & 0.00 & 0,22 & $\mathrm{RE}$ \\
\hline & & & $(0.64)$ & $(-4.71)^{* * *}$ & $(0.82)$ & $(0.19)$ & $(-0.04)$ & & \\
\hline
\end{tabular}

***, **, * significant at $0.01,0.05$ e 0.10 respectively. Robust $\mathrm{t}(\mathrm{z})$ statistics are in parentheses.

The panels were estimated using Feasible Generalized Least Squares - FGLS. For all regressions, the independent variable and control variables were lagged in one period $(\mathrm{t}-1)$.

Regression panel B1: Book_Lev1 ${ }_{i t}=\beta_{0}+\beta_{1} M B_{\text {efwal }, i t-1}+\beta_{2} M B_{i, t-1}+\beta_{3}$ Tang $_{i, t-1}+\beta_{4} \operatorname{Prof}_{i, t-1}+\beta_{5}$ Size $_{i, t-1}+u_{i t}$

Regression panel B2: $\quad$ Market_Lev1 ${ }_{i t}=\beta_{0}+\beta_{1} M B_{\text {efwal }, i t-1}+\beta_{2} M B_{i, t-1}+\beta_{3}$ Tang $_{i, t-1}+\beta_{4} \operatorname{Pr}_{i, t-1}+\beta_{5}$ Size $_{i, t-1}+u_{i t}$

According to the results of panel B1 of table 5, the coefficient for the explanatory variable MB showed no statistical significance in any of the subsamples. The control variable size showed statistical significance at $10 \%$ for IPO+1, as expected. 
These results for book leverage measures cannot allow the observance of market timing in the Brazilian market and, therefore, its persistence is also not confirmed, since the variable Mbefwal does not present statistical significance for any of the subsamples.

The panel B2 of table 5 presents results more consistent for the market leverage measures. This regression presented to the variable MB the expected sign and a statistically significance at the $1 \%$ level for all years. The explanation of the regression, measured by $\mathrm{R}^{2}$, obtained a maximum value of $31.6 \%$ in IPO+1 and a minimum of $20.7 \%$ in IPO+6.

According to these results one may infer that the MB ratio affects the levels of corporate leverage in the short-run and that the occurrence of equity market timing is just a local opportunity caused by the overvaluation of companies based on market inefficiencies and market mispricing, but whose effect is quickly rebalanced.

Likewise, on the results of panel B2 in table 5, the variable MBefwa1 was not statistically significant, showing that the weighted average of the historical values of the MB has no influence on the financing decisions of the Brazilian companies, a sign contrary to the theory, because according to Baker and Wurgler (2002), the weighted average of past debt and shares issuance would have a greater explanatory power than a particular number of lagged $\mathrm{MB}$, since it would better capture which issuance of shares and debt would be the most significant within the entire series. In this case, the results do not allow us to confirm the hypothesis of the persistence of the equity market timing theory in the long run for the Brazilian stock market.

The results for the measures of companies' leverage by the total financial debt, reported in panels B3 and B4, do not differ much from the results presented in panels B1 and B2 previously analyzed and refer to conclusions similar to those previously described.

The dependent variable book leverage measured as total financial debt was not statistically consistent in any of the series for the variable MB. As for the measure of market leverage by total debt, the results of the panel B4 in table 6 were significant at $1 \%$ for the independent variable MB in all years and a negative sign for the coefficient, as expected. $\mathrm{R}^{2}$ values obtained were lower than those recorded in panel $\mathrm{B} 2$, with a maximum score of $15.6 \%$ for IPO+1. While presenting the expected sign, the independent variable MBefwa2 continued not being statistically significant for any of the subsamples, reinforcing the observation that the effects of market timing are not persistent in the long-run.

Table 6. Determinants of leverage (total gross financial debt)

\begin{tabular}{|c|c|c|c|c|c|c|c|c|c|}
\hline & N. Obs & Constant & MBefwa2 t-1 & MB t-1 & Tang $\mathrm{t}-1$ & Prof $t-1$ & Size $\mathrm{t}-1$ & $\mathrm{R}^{2}$ & Hausmann's Test \\
\hline \multicolumn{10}{|c|}{ Panel B3: Book_Lev2 } \\
\hline \multirow{2}{*}{ IPO + 1} & 238 & -0.07 & -0.01 & 0.00 & 0.17 & 0.03 & 0.02 & 0.02 & $\mathrm{RE}$ \\
\hline & & & $(-1.00)$ & $(0.04)$ & $(1.92)^{*}$ & $(0.29)$ & $(1.45)$ & & \\
\hline \multirow{2}{*}{$\mathrm{IPO}+2$} & 219 & 0.00 & -0.01 & 0.00 & 0.18 & 0.03 & 0.01 & 0.01 & $\mathrm{RE}$ \\
\hline & & & $(-0.99)$ & $(0.23)$ & $(1.70)^{*}$ & $(0.32)$ & $(1.08)$ & & \\
\hline \multirow[t]{2}{*}{$\mathrm{IPO}+3$} & 206 & -0.20 & -0.01 & -0.01 & 0.19 & -0.01 & 0.03 & 0.00 & $\mathrm{FE}$ \\
\hline & & & $(-0.72)$ & $(-0.33)$ & $(3.04)^{* * *}$ & $(-0.05)$ & $(1.31)$ & & \\
\hline \multirow[t]{2}{*}{$\mathrm{IPO}+4$} & 182 & -0.06 & -0.01 & -0.01 & 0.18 & 0.05 & 0.02 & 0.02 & FE \\
\hline & & & $(-0.76)$ & $(-0.30)$ & $(1.27)$ & $(0.23)$ & $(0.61)$ & & \\
\hline \multirow[t]{2}{*}{$\mathrm{IPO}+5$} & 174 & -0.07 & -0.01 & -0.01 & 0.17 & 0.03 & 0.02 & 0.02 & FE \\
\hline & & & $(-0.75)$ & $(-0.30)$ & $(1.19)$ & $(0.14)$ & $(0.64)$ & & \\
\hline \multirow[t]{2}{*}{$\mathrm{IPO}+6$} & 164 & -0.01 & -0.01 & -0.01 & 0.17 & 0.04 & 0.01 & 0.04 & FE \\
\hline & & & $(-0.94)$ & $(-0.27)$ & $(1.16)$ & $(0.20)$ & $(0.49)$ & & \\
\hline \multirow[t]{2}{*}{$\mathrm{IPO}+7$} & 152 & -0.06 & -0.01 & 0.00 & 0.15 & -0.06 & 0.02 & 0.03 & $\mathrm{FE}$ \\
\hline & & & $(-1.01)$ & $(0.04)$ & $(1.08)$ & $(-0.32)$ & $(0.58)$ & & \\
\hline
\end{tabular}




\begin{tabular}{|c|c|c|c|c|c|c|c|c|c|}
\hline \multicolumn{10}{|c|}{ Panel B4: Market_Lev2 } \\
\hline \multirow[t]{2}{*}{$\mathrm{IPO}+1$} & 238 & 0.17 & -0.01 & -0.06 & 0.15 & -0.07 & 0.01 & 0.16 & $\mathrm{RE}$ \\
\hline & & & $(-1.02)$ & $(-3.18)^{* * *}$ & $(2.16)^{* *}$ & $(-0.42)$ & $(0.69)$ & & \\
\hline \multirow[t]{2}{*}{$\mathrm{IPO}+2$} & 219 & 0.27 & -0.01 & -0.05 & 0.16 & -0.17 & 0.00 & 0.13 & $\mathrm{RE}$ \\
\hline & & & $(-0.91)$ & $(-2.80)^{* * *}$ & $(1.86)^{*}$ & $(-0.82)$ & $(0.28)$ & & \\
\hline \multirow[t]{2}{*}{$\mathrm{IPO}+3$} & 206 & 0.39 & -0.01 & -0.06 & 0.18 & -0.06 & 0.00 & 0.11 & $\mathrm{RE}$ \\
\hline & & & $(-0.80)$ & $(-2.76)^{* * *}$ & $(1.81)^{*}$ & $(-0.27)$ & $(-0.27)$ & & \\
\hline \multirow[t]{2}{*}{$\mathrm{IPO}+4$} & 182 & 0.45 & -0.01 & -0.11 & 0.16 & 0.04 & 0.00 & 0.04 & $\mathrm{RE}$ \\
\hline & & & $(-0.92)$ & $(-3.18)^{* * *}$ & $(1.34)$ & $(0.17)$ & $(-0.24)$ & & \\
\hline \multirow[t]{2}{*}{$\mathrm{IPO}+5$} & 174 & 0.43 & -0.01 & -0.11 & 0.17 & 0.04 & 0.00 & 0.04 & $\mathrm{RE}$ \\
\hline & & & $(-0.93)$ & $(-3.11)^{* * *}$ & $(1.34)$ & $(0.18)$ & $(-0.22)$ & & \\
\hline \multirow[t]{2}{*}{$\mathrm{IPO}+6$} & 164 & 0.44 & -0.01 & -0.12 & 0.17 & 0.10 & 0.00 & 0.03 & $\mathrm{RE}$ \\
\hline & & & $(-1.15)$ & $(-3.02)^{* * * *}$ & (1.34) & $(0.40)$ & $(-0.21)$ & & \\
\hline \multirow[t]{2}{*}{$\mathrm{IPO}+7$} & 152 & 0.40 & -0.02 & -0.11 & 0.18 & -0.01 & 0.00 & 0.04 & $\mathrm{RE}$ \\
\hline & & & $(-1.18)$ & $(-2.83)^{* * *}$ & $(1.31)$ & $(-0.04)$ & $(-0.14)$ & & \\
\hline
\end{tabular}

****** significant at $0,01,0,05$ e 0,10 , respectively. Robust $\mathrm{t}(\mathrm{z})$ statistics are in parentheses.

The panels were estimated using Feasible Generalized Least Squares - FGLS. For all regressions, the independent variable and control variables were lagged in one period $(\mathrm{t}-1)$.

Regression panel B3: Book_Lev $2_{i t}=\beta_{0}+\beta_{1} M B_{\text {efwa } 2, i t-1}+\beta_{2} M B_{i, t-1}+\beta_{3}$ Tang $_{i, t-1}+\beta_{4} \operatorname{Pr} o f_{i, t-1}+\beta_{5}$ Size $_{i, t-1}+u_{i t}$

Regression panel B4: Market_Lev $2_{i t}=\beta_{0}+\beta_{1} M B_{\text {efwa } 2, i t-1}+\beta_{2} M B_{i, t-1}+\beta_{3}$ Tang $g_{i, t-1}+\beta_{4} \operatorname{Pr} o f_{i, t-1}+\beta_{5}$ Size $i, t-1+u_{i t}$

Finally, tables 7 and 8 reports the econometric tests where five additional control variables were added as a way to expand the investigation of the determinants of the capital structure of the firms.

Table 7. Determinants of book leverage (total gross debt): additional control variables

\begin{tabular}{|c|c|c|c|c|c|c|c|c|c|c|c|c|c|c|}
\hline & $\begin{array}{l}\text { N. } \\
\text { Obs }\end{array}$ & Constant & $\begin{array}{c}\text { MBefwa1 } \\
\text { t-1 }\end{array}$ & $\begin{array}{c}\text { MB } \\
t-1\end{array}$ & $\begin{array}{c}\text { Tang } \\
\mathrm{t}-1\end{array}$ & $\begin{array}{c}\text { Prof } \\
\mathrm{t}-1\end{array}$ & $\begin{array}{c}\text { Size } \\
\mathrm{t}-1\end{array}$ & $\begin{array}{c}\text { Econ_- } \\
\text { Growth t-1 }\end{array}$ & $\begin{array}{c}\text { Interest } \\
\mathrm{t}-1\end{array}$ & $\begin{array}{c}\text { Exch } \\
\mathrm{t}-1\end{array}$ & $\begin{array}{c}\text { Risk } \\
\mathrm{t}-1\end{array}$ & $\begin{array}{l}\mathrm{Liq} \\
\mathrm{t}-1\end{array}$ & $\mathrm{R}^{2}$ & $\begin{array}{c}\text { Hausmann's } \\
\text { Test }\end{array}$ \\
\hline $\mathrm{IPO}+1$ & 238 & 0.31 & $\begin{array}{c}0.02 \\
(0.87)\end{array}$ & $\begin{array}{c}-0.03 \\
(-1.52)\end{array}$ & $\begin{array}{c}-0.05 \\
(-0.32)\end{array}$ & $\begin{array}{c}0.17 \\
(1.12)\end{array}$ & $\begin{array}{c}0.01 \\
(0.21)\end{array}$ & $\begin{array}{c}0.02 \\
(0.31)\end{array}$ & $\begin{array}{c}-0.18 \\
(-0.85)\end{array}$ & $\begin{array}{c}-0.04 \\
(-0.68)\end{array}$ & $\begin{array}{c}0.07 \\
(0.50)\end{array}$ & $\begin{array}{c}-0.01 \\
(-3.77)^{* * *}\end{array}$ & 0.18 & $\mathrm{FE}$ \\
\hline $\mathrm{IPO}+2$ & 219 & 0.31 & $\begin{array}{c}0.02 \\
(0.86)\end{array}$ & $\begin{array}{c}-0.03 \\
(-1.51)\end{array}$ & $\begin{array}{c}-0.05 \\
(-0.32)\end{array}$ & $\begin{array}{c}0.17 \\
(1.12)\end{array}$ & $\begin{array}{c}0.01 \\
(0.21)\end{array}$ & $\begin{array}{c}0.02 \\
(0.31)\end{array}$ & $\begin{array}{c}-0.18 \\
(-0.84)\end{array}$ & $\begin{array}{c}-0.04 \\
(-0.67)\end{array}$ & $\begin{array}{c}0.07 \\
(0.50)\end{array}$ & $\begin{array}{c}-0.01 \\
(-3.75)^{* * *}\end{array}$ & 0.18 & FE \\
\hline $\mathrm{IPO}+3$ & 206 & 0.30 & $\begin{array}{c}0.02 \\
(0.81)\end{array}$ & $\begin{array}{c}-0.03 \\
(-1.43)\end{array}$ & $\begin{array}{c}-0.05 \\
(-0.33)\end{array}$ & $\begin{array}{c}0.16 \\
(0.94)\end{array}$ & $\begin{array}{c}0.01 \\
(0.32)\end{array}$ & $\begin{array}{c}0.02 \\
(0.27)\end{array}$ & $\begin{array}{c}-0.17 \\
(-0.79)\end{array}$ & $\begin{array}{c}-0.03 \\
(-0.63)\end{array}$ & $\begin{array}{c}0.12 \\
(0.82)\end{array}$ & $\begin{array}{c}-0.01 \\
(-3.71)^{* * *}\end{array}$ & 0.18 & FE \\
\hline $\mathrm{IPO}+4$ & 182 & 0.60 & $\begin{array}{c}0.01 \\
(0.72)\end{array}$ & $\begin{array}{l}-0.02 \\
(-0.89)\end{array}$ & $\begin{array}{c}-0.07 \\
(-0.43)\end{array}$ & $\begin{array}{c}0.24 \\
(1.27)\end{array}$ & $\begin{array}{c}-0.01 \\
(-0.24)\end{array}$ & $\begin{array}{c}0.01 \\
(0.13)\end{array}$ & $\begin{array}{l}-0.15 \\
(-0.72)\end{array}$ & $\begin{array}{c}-0.02 \\
(-0.38)\end{array}$ & $\begin{array}{c}0.10 \\
(0.59)\end{array}$ & $\begin{array}{c}-0.01 \\
(-3.64)^{* * *}\end{array}$ & 0.23 & FE \\
\hline $\mathrm{IPO}+5$ & 174 & 0.65 & $\begin{array}{c}0.02 \\
(0.97)\end{array}$ & $\begin{array}{c}-0.01 \\
(-0.57)\end{array}$ & $\begin{array}{c}-0.10 \\
(-0.67)\end{array}$ & $\begin{array}{c}0.27 \\
(1.78)^{*}\end{array}$ & $\begin{array}{c}0.01 \\
(0.47)\end{array}$ & $\begin{array}{c}-0.01 \\
(-0.20)\end{array}$ & $\begin{array}{c}-0.10 \\
(-0.41)\end{array}$ & $\begin{array}{c}-0.01 \\
(-0.22)\end{array}$ & $\begin{array}{c}0.11 \\
(0.59)\end{array}$ & $\begin{array}{c}-0.01 \\
(-3.79)^{* * *}\end{array}$ & 0.29 & $\mathrm{RE}$ \\
\hline $\mathrm{IPO}+6$ & 164 & 0.72 & $\begin{array}{c}0.02 \\
(0.76)\end{array}$ & $\begin{array}{c}-0.01 \\
(-0.33)\end{array}$ & $\begin{array}{c}-0.11 \\
(-0.72)\end{array}$ & $\begin{array}{c}0.25 \\
(1.59)\end{array}$ & $\begin{array}{c}0.01 \\
(0.43)\end{array}$ & $\begin{array}{c}-0.02 \\
(-0.31)\end{array}$ & $\begin{array}{c}-0.06 \\
(-0.24)\end{array}$ & $\begin{array}{l}-0.01 \\
(-0.09)\end{array}$ & $\begin{array}{c}0.11 \\
(0.61)\end{array}$ & $\begin{array}{c}-0.01 \\
(-3.79)^{* * * *}\end{array}$ & 0.31 & $\mathrm{RE}$ \\
\hline $\mathrm{IPO}+7$ & 152 & 0.72 & $\begin{array}{c}0.02 \\
(0.75)\end{array}$ & $\begin{array}{c}-0.01 \\
(-0.28)\end{array}$ & $\begin{array}{c}-0.11 \\
(-0.66)\end{array}$ & $\begin{array}{c}0.25 \\
(1.48)\end{array}$ & $\begin{array}{c}0.00 \\
(0.33)\end{array}$ & $\begin{array}{c}-0.02 \\
(-0.27)\end{array}$ & $\begin{array}{l}-0.08 \\
(-0.30)\end{array}$ & $\begin{array}{c}-0.01 \\
(-0.17)\end{array}$ & $\begin{array}{c}0.10 \\
(0.54)\end{array}$ & $\begin{array}{c}-0.01 \\
(-3.58)^{* * *}\end{array}$ & 0.32 & $\mathrm{RE}$ \\
\hline
\end{tabular}

$* * * * * *$ significant at $0,01,0,05$ e 0,10 , respectively. Robust $\mathrm{t}(\mathrm{z})$ statistics are in parentheses.

The panel was estimated using Feasible Generalized Least Squares - FGLS. For all regressions, the independent variable, control variables and alternative control variables were lagged in one period $(\mathrm{t}-1)$.

Regression: Book_Lev1 $_{i t}=\beta_{0}+\beta_{1} M B_{\text {efwa } 1, i t-1}+\beta_{2} M B_{i, t-1}+\beta_{3}$ Tang $_{i, t-1}+\beta_{4} \operatorname{Prof}{ }_{i, t-1}+\beta_{5}$ Size $_{i, t-1}+\beta_{6}$ Econ $_{-}$Growth $_{i, t-1}$ $+\beta_{7}$ Interest $_{i, t-1}+\beta_{8}$ Exch $_{i, t-1}+\beta_{9}$ Risk $_{i, t-1}+\beta_{10}$ Liq $_{i, t-1}+u_{i t}$ 
Table 8. Determinants of market leverage (total gross debt): additional control variables

\begin{tabular}{|c|c|c|c|c|c|c|c|c|c|c|c|c|c|c|}
\hline & $\begin{array}{l}\mathrm{N} . \\
\text { Obs }\end{array}$ & Constant & $\begin{array}{c}\text { MBefwa1 } \\
\text { t-1 }\end{array}$ & MB t-1 & $\begin{array}{c}\text { Tang } \\
\mathrm{t}-1\end{array}$ & $\begin{array}{c}\text { Prof } \\
\mathrm{t}-1\end{array}$ & $\begin{array}{l}\text { Size } \\
\mathrm{t}-1\end{array}$ & $\begin{array}{c}\text { Econ Growth } \\
\mathrm{t}-1\end{array}$ & Interestt-1 & Excht-1 & Risk t-1 & Liq $\mathrm{t}-1$ & $\mathrm{R}^{2}$ & $\begin{array}{c}\text { Hausmann's } \\
\text { Test }\end{array}$ \\
\hline \multirow{2}{*}{$\mathrm{IPO}+1$} & \multirow[t]{2}{*}{238} & \multirow[t]{2}{*}{2.27} & 0.01 & -0.08 & -0.02 & -0.15 & 0.03 & -0.15 & -0.58 & 0.02 & 0.25 & 0.00 & 0.32 & $\mathrm{FE}$ \\
\hline & & & $(0.36)$ & $(-3.06)^{* * *}$ & $(-0.23)$ & $(-0.61)$ & $(1.20)$ & $(-3.68) * * *$ & $(-2.86) * * *$ & $(0.38)$ & $(0.89)$ & $(0.375)$ & & \\
\hline \multirow{2}{*}{$\mathrm{IPO}+2$} & \multirow[t]{2}{*}{219} & \multirow[t]{2}{*}{2.27} & 0.01 & -0.08 & -0.02 & -0.15 & 0.03 & -0.15 & -0.58 & 0.02 & 0.25 & 0.00 & 0.27 & $\mathrm{FE}$ \\
\hline & & & $(0.36)$ & $(-3.04) * * *$ & $(-0.23)$ & $(-0.61)$ & (1.19) & $(-3.66) * * *$ & $(-2.84)^{* * *}$ & $(0.37)$ & $(0.89)$ & $(-3.86)^{* * *}$ & & \\
\hline \multirow{2}{*}{$\mathrm{IPO}+3$} & \multirow[t]{2}{*}{206} & \multirow[t]{2}{*}{2.26} & 0.01 & -0.09 & 0.00 & -0.03 & 0.03 & -0.14 & -0.61 & 0.01 & 0.22 & 0.00 & 0.28 & $\mathrm{FE}$ \\
\hline & & & $(0.22)$ & $(-3.06)^{* * *}$ & $(0.02)$ & $(-0.10)$ & $(0.88)$ & $(-3.41)^{* * *}$ & $(-3.08) * * *$ & $(0.18)$ & $(0.75)$ & $(-3.91)^{* * *}$ & & \\
\hline \multirow{2}{*}{$\mathrm{IPO}+4$} & \multirow[t]{2}{*}{182} & \multirow[t]{2}{*}{2.40} & 0.01 & -0.13 & -0.04 & 0.07 & 0.00 & -0.11 & -0.75 & -0.01 & 0.17 & -0.01 & 0.35 & $\mathrm{RE}$ \\
\hline & & & $(0.30)$ & $(-3.95)^{* * *}$ & $(-0.46)$ & $(0.29)$ & $(-0.10)$ & $(-3.85)^{* * *}$ & $(-3.82) * * *$ & $(-0.14)$ & $(0.55)$ & $(-4.32) * * *$ & & \\
\hline \multirow{2}{*}{$\mathrm{IPO}+5$} & \multirow[t]{2}{*}{174} & \multirow[t]{2}{*}{2.20} & 0.01 & -0.13 & 0.01 & 0.16 & 0.01 & -0.12 & -0.69 & 0.00 & 0.25 & -0.01 & 0.28 & $\mathrm{FE}$ \\
\hline & & & $(0.19)$ & $(-3.45)^{* * *}$ & $(0.13)$ & $(0.55)$ & $(0.36)$ & $(-3.12)^{* * *}$ & $(-3.40) * * *$ & $(-0.01)$ & $(0.73)$ & $(-3.69)^{* * *}$ & & \\
\hline \multirow{2}{*}{$\mathrm{IPO}+6$} & \multirow[t]{2}{*}{164} & \multirow[t]{2}{*}{2.31} & 0.02 & -0.15 & -0.02 & 0.13 & 0.00 & -0.11 & -0.67 & 0.00 & 0.01 & -0.01 & 0.34 & $\mathrm{RE}$ \\
\hline & & & $(0.56)$ & $(-4.29) * * *$ & $(-0.19)$ & $(0.50)$ & $(-0.10)$ & $(-3.67) * * *$ & $(-3.24)^{* * *}$ & $(-0.02)$ & $(0.29)$ & $(-4.04) * * *$ & & \\
\hline \multirow{2}{*}{$\mathrm{IPO}+7$} & \multirow[t]{2}{*}{152} & \multirow[t]{2}{*}{2.32} & 0.02 & -0.14 & -0.02 & 0.04 & 0.00 & -0.11 & -0.65 & 0.01 & 0.00 & -0.01 & 0.36 & $\mathrm{RE}$ \\
\hline & & & $(0.60)$ & $(-4.03)^{* * * *}$ & $(-0.21)$ & $(0.15)$ & $(-0.11)$ & $(-3.38)^{* * *}$ & $(-2.95)^{* * *}$ & $(0.17)$ & $(-0.00)$ & $(-3.82)^{* * *}$ & & \\
\hline
\end{tabular}

$* * * * * *$ significant at $0,01,0,05$ e 0,10 , respectively. Robust $\mathrm{t}(\mathrm{z})$ statistics are in parentheses.

The panel was estimated using Feasible Generalized Least Squares - FGLS. For all regressions, the independent variable, control variables and alternative control variables were lagged in one period $(\mathrm{t}-1)$.

Regression: Market_Lev1 $_{i t}=\beta_{0}+\beta_{1} M B_{\text {efwal } i t-1}+\beta_{2} M B_{i, t-1}+\beta_{3}$ Tang $_{i, t-1}+\beta_{4} \operatorname{Prof} f_{i, t-1}+\beta_{5}$ Size $_{i, t-1}+\beta_{6}$ Econ_Growth $_{i, t-1}$ $+\beta_{7}$ Interest $_{i, t-1}+\beta_{8}$ Exch $_{i, t-1}+\beta_{9}$ Risk $_{i, t-1}+\beta_{10}$ Liq $_{i, t-1}+u_{i t}$

The results in table 7, which examined the book leverage by total debt, allowed us to confirm statistical significance for the control variable liquidity, added at this stage, with a level of $1 \%$ for all years and with a negative sign, according to expected, with a greater explanatory power of the regression obtained by $\mathrm{R}^{2}$ of the subsample IPO+7, which was $31.5 \%$.

On the other hand, the results in table 8 , which regressed the market leverage by total debt, the explanatory variable MB showed statistical significance at $1 \%$ for all years as well as a negative sign for the coefficient, in accordance to the expectations, rejecting the hypothesis of non-existence of market timing for the Brazilian capital market and indicating its existence in the short-run. Once again, in both panels, the proxy MBefwa did not show any statistical significance and presented a sign contrary to the expectations, which shows that the effects of market timing do not have long-term persistence.

Table 8, additionally, showed statistically significant results in all years for the additional control variables GDP, interest rates and liquidity, all with a negative sign and statistically significant. On this panel we may also see a greater explanatory power for the model, as there was an increase of $\mathrm{R}^{2}$, which showed a minimum value of $27.2 \%$ in IPO+2 and a maximum of $35.7 \%$ in IPO+7.

As in the procedures presented above, the last stage of testing regressed both book leverage and market leverage by the total financial debt (not reported) (Note 3). The results presented in these panels were similar to the results reported in tables 7 and 8 .

The results obtained by the different tests that examined the effects of market timing on the capital structure of the public companies in Brazil show that companies that went to public between 1997 and 2007 made use of windows of opportunities in the Brazilian capital market, in which they found moments of overvaluation of their assets and, respectively, the low-cost of equity to issue shares, leading to the evidence of the occurrence of the theory in Brazil. However, it was found that these effects are transient, indicating that managers reduce the leverage levels of their companies according to the appropriate time of the market, taking advantage of these windows, but that this strategy does not present support in the long-run, a sign contrary to what theory predicts. 


\section{Conclusion}

This study tested the theory of equity market timing for the Brazilian capital market, by conducting econometric procedures for an initial sample of 121 companies that conducted initial public offering between 1997 and 2007. The results found evidence of the existence of the theory for the capital market in Brazil. However, in spite of the fact that the market timing has been observed in the short-run, its effects were not persistent in the long-run, contrasting with the results obtained by Baker and Wurgler (2002) for the US market but finding similarities with the results of the work of Rossi Junior and Céspedes (2008) and Rossi Junior and Marotta (2010) for the Brazilian market, although contrary to the results obtained by Basso, Mendes and Kaio (2009) for this same market.

The dependent variable market-to-book was negative and statistically significant for both measures of market leverage, signaling that the overvaluation in stock prices of the Brazilian public companies would lead to an opportunistic behavior by managers, who would take advantage of windows of opportunities in the market to issue shares. Through these results, the hypothesis of the existence of market timing in the short-run is demonstrated.

On the other hand, the main explanatory variable capable of signaling the long-term effects of the theory, Mbefwa, did not present statistically significant results, which indicated that the market timing would be just a one-off opportunity and that its effects could not be sustained in the long-run.

Other determinants of capital structure, such as tangibility and liquidity, and also the macroeconomic variables GDP and interest rates showed significant results that contribute to the explanation of the behavior of public companies when determining their capital structure.

This study presents the following contributions to the capital structure literature: a) expands the documented evidence on equity market timing, until then heavily concentrated in developed economies, to emerging countries such as Brazil; b) strengthens the empirical support for the existence of equity market timing in the short-run, especially in emerging markets; c) strengthens the evidence for the existence of differences between the United States and other countries regarding the long-term persistence of this phenomenon.

\section{Acknowledgements}

We wish to thank the anonymous referees for significant comments. All remaining errors are our own.

\section{References}

Alti, A. (2006). How Persistent Is the Impact of Market Timing on Capital Structure? The Journal of Finance, 61(4), 1681-1710. http://dx.doi.org/10.1111/j.1540-6261.2006.00886.x

Arellano, M. (1987). PRACTITIONERS' CORNER: Computing Robust Standard Errors for Within-groups Estimators. Oxford Bulletin of Economics and Statistics, 49(4), 431-434. http://dx.doi.org/10.1111/j.1468-0084.1987.mp49004006.x

Baker, M., \& Wurgler, J. (2002). Market Timing and Capital Structure. The Journal of Finance, 57(1), 1-32. http://dx.doi.org/10.1111/1540-6261.00414

Baltagi, B. H., Bresson, G., \& Pirotte, A. (2006). Joint LM test for homoskedasticity in a one-way error component model. Journal of Econometrics, 134(2), 401-417. http://dx.doi.org/10.1016/j.jeconom.2005.06.029

Baltagi, B., \& Wu, P. (1999). Unequally spaced panel data regressions with AR (1) disturbances. Econometric Theory, 15, 814-823. http://dx.doi.org/10.1017/S0266466699156020

Barros, L. A. (2005). Valor da empresa e estrutura de capital: Estudo em condições de assimetria no mercado brasileiro. São Paulo: Saint Paul.

Basso, L., Mendes, E., \& Kaio, E. (2009). Estrutura de capital e janelas de oportunidade: testes no mercado brasileiro. RAM - Revista de Administração Mackenzie, 10(6), 78-100. http://dx.doi.org/10.1590/S1678-69712009000600006

Bhargava, A., Franzini, L., \& Narendranathan, W. (1982). Serial Correlation and the Fixed Effects Model. The Review of Economic Studies, 49(4), 533. http://dx.doi.org/10.2307/2297285

Breusch, T. S., \& Pagan, A. R. (1980). The Lagrange Multiplier Test and its Applications to Model Specification in Econometrics. The Review of Economic Studies, 47(1), 239-253. http://dx.doi.org/10.2307/2297111

De Bie, T., \& De Haan, L. (2007). Market Timing and Capital Structure: Evidence for Dutch Firms. De Economist, 155(2), 183-206. http://dx.doi.org/10.1007/s10645-007-9054-1 
Elliott, W. B., Koëter-Kant, J., \& Warr, R. S. (2007). A valuation-based test of market timing. Journal of Corporate Finance, 13(1), 112-128. http://dx.doi.org/10.1016/j.jcorpfin.2006.12.001

Flannery, M. J., \& Rangan, K. P. (2006). Partial adjustment toward target capital structures. Journal of Financial Economics, 79(3), 469-506. http://dx.doi.org/10.1016/j.jfineco.2005.03.004

Froot, K. A. (1989). Consistent Covariance Matrix Estimation with Cross-Sectional Dependence and Heteroskedasticity in Financial Data. The Journal of Financial and Quantitative Analysis, 24(3), 333-355. http://dx.doi.org/10.2307/2330815

Guney, Y., \& Iqbal-Hussain, H. (2010). Capital Structure and IPO Market Timing in the UK. In Behavioural Finance Working Group Conference: Fairness, Trust and Emotions in Finance (pp. 1-34). London, UK.

Hovakimian, A. (2006). Are Observed Capital Structures Determined by Equity Market Timing? Journal of Financial and Quantitative Analysis, 41(01), 221. http://dx.doi.org/10.1017/S0022109000002489

Huang, R., \& Ritter, J. R. (2005). Testing the Market Timing Theory of Capital Structure. University of Florida Working Paper, 1-43.

Myers, S. C. (1984). The Capital Structure Puzzle. The Journal of Finance, 39(3), 575. http://dx.doi.org/10.2307/2327916

Myers, S. C., \& Majluf, N. S. (1984). Corporate financing and investment decisions when firms have information that investors do not have. Journal of Financial Economics, 13(2), 187-221. http://dx.doi.org/10.1016/0304-405X(84)90023-0

Rajan, R. G., \& Zingales, L. (1995). What Do We Know about Capital Structure? Some Evidence from $\begin{array}{lllll}\text { International Data. The Journal of Finance, } & 50(5), & 1421 .\end{array}$ http://dx.doi.org/10.1111/j.1540-6261.1995.tb05184.x

Rogers, W. H. (1993). Regression standard errors in clustered samples. Stata Technical Bulletin Reprints, 3, 8894.

Rossi Júnior, J. L., \& Céspedes, I. (2008). Testes Empíricos sobre Market Timing na Determinação da Estrutura de Capital das Empresas Brasileiras. In XXXII Encontro da ANPAD (pp. 1-16). Rio de Janeiro.

Rossi Júnior, J. L., \& Marotta, M. (2010). Equity Market Timing: Testando através dos IPOs no Mercado Brasileiro. Revista Brasileira de Finanças, 8(1), 85-101.

White, H. (1980). A heteroskedasticity-consistent covariance matrix estimator and a direct test fro heteroskedasticity. Econometrica, 48(4), 817-838. http://dx.doi.org/10.2307/1912934

\section{Notes}

Note 1. The total gross financial debt follows the structure proposed by Barros (2005) and is expressed by: FD = (STD + STD') + (LTD + LTD') + ACC, where STD represents short-term debt, STD' short-term debentures, LTD the long-term debt, LTD' long-term debentures, and ACC advances on exchange contracts.

Note 2. In the regressions of panels A1 and A2 a fifth variable is included, called lagged leverage, which according to Baker and Wurgler (2002) aims to control the effects of debt levels when they are close to the limits of the minimum $(0 \%)$ and the maximum $(100 \%)$. Not to control these effects means that the change in the leverage of the firm can only go in one direction, regardless of the values found in other variables, distorting the effects of these variables on the leverage.

Note 3. Table 9 presents the results for the regressions based on book leverage and market leverage by the total gross financial debt, and it includes the five additional control variables. The authors may make this table available if required by the reader.

\section{Copyrights}

Copyright for this article is retained by the author(s), with first publication rights granted to the journal.

This is an open-access article distributed under the terms and conditions of the Creative Commons Attribution license (http://creativecommons.org/licenses/by/3.0/). 